\title{
Root growth of upland rice genotypes as influenced by nitrogen fertilization
}

\author{
N. K. Fageria ${ }^{A}$

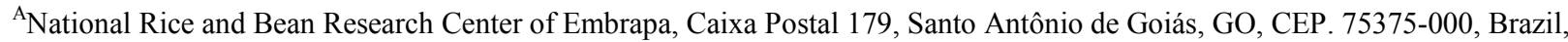 \\ E mail fageria@cnpaf.embrapa.br
}

\begin{abstract}
The Plant root system is an important organ which supplies water and nutrients to plants. Information is limited on influence of nitrogen fertilization on upland rice root growth. A greenhouse experiment was conducted to evaluate the influence of nitrogen fertilization on root growth of 20 upland rice genotypes. The $\mathrm{N}$ rates used were $0 \mathrm{mg} / \mathrm{kg}$ (low) and $300 \mathrm{mg} / \mathrm{kg}$ (high) of soil. Nitrogen X genotype interactions for root length and root dry weight were highly significant $(\mathrm{P}<0.01)$, indicating that differences among genotypes were not consistent at two $\mathrm{N}$ rates. Overall, greater root length and root dry weight were obtained at an $\mathrm{N}$ fertilization rate of $300 \mathrm{mg} / \mathrm{kg}$ compared with the $0 \mathrm{mg} \mathrm{N} / \mathrm{kg}$ soil. However, genotypes differ significantly in producing root length and root dry weight. Nitrogen fertilization produced fine roots and more root hairs compared with control treatment. Based on root dry weight efficiency index (RDWEI) for N use efficiency, $70 \%$ genotypes were classified as efficient, $15 \%$ were classified as moderately efficient and $15 \%$ were classified as inefficient. Root dry weight efficiency index trait can be incorporated in upland rice for improving water and nutrient efficiency in favor of higher yields.
\end{abstract}

\section{Key Words}

Oryza sativa L., Oxisol, root dry weight efficiency index, shoot-root ratio.

\section{Introduction}

Root system is an important organ of plants. It absorbs water and nutrients from soil and supply to plant tops for their metabolic activities. Roots also give plants a mechanical support and supply hormones which help plants in many physiological and biochemical processes associated with growth and development. A vigorous root system is responsible for development of healthy plants and consequently higher yields. Roots which are left in the soil after crop harvest, improve soil organic matter content, nitrogen cycle and microbial activities (Sainju et al. 2005). All these activities improve soil structure, soil water holding capacity, water infiltration rate in the soil and reduce soil bulk density and soil erosion which ultimately leads to higher soil productivity. Root growth is controlled genetically and also influenced by environmental factors. Environmental factors which influence plant root growth are soil temperature, soil moisture content, solar radiation and soil physical, chemical and biological properties (Fageria 2009). Most of the root biomass of annual crops is located in the $0-20 \mathrm{~cm}$ soil depth. This may be associated with large amount of organic matter, nutrient accumulation and water availability in the top soil layer compared to lower soil depths (Sainju et al. 2005). In most of the research articles data related to plant tops growth and development are presented. Research data related to growth and development of crop root systems are limited. The objective of this study was to evaluate influence of nitrogen fertilization on root growth of twenty upland rice genotypes.

\section{Materials and methods}

The experiment was conducted in the greenhouse of National Rice and Bean Research Center of EMBRAPA, Santo Antôio de Goias, Brazil. The soil used in the experiment was an Oxisol. The genotypes used were: BRA01506, BRA01596, BRA01600, BRA02535, BRA02601, BRA032033, BRA032039, BRA032048, BRA032051, BRA042094, BRA042156, BRA042160, BRA052015, BRA052023, BRA052033, BRA052034, BRA052045, BRA052053, BRS Primavera, BRS Sertaneja. The N levels used were low $(0 \mathrm{mg} / \mathrm{kg})$ and high $(300 \mathrm{mg} / \mathrm{kg})$ and supplied through urea. Half of the $\mathrm{N}$ was applied at sowing and remaining half as topdressing 45 days after sowing. Four plants were maintained in each pot after germination. Experiments were conducted in plastic pots with $9 \mathrm{~kg}$ of soil in each pot. At the time of sowing, each pot received $200 \mathrm{mg} \mathrm{P}$ as triple super phosphate, $200 \mathrm{mg} \mathrm{K}$ as potassium chloride and $10 \mathrm{mg} \mathrm{Zn/kg}$ of soil as zinc sulfate. Each pot also received $10 \mathrm{~g}$ dolomitic lime four weeks before sowing. The liming material was having $33 \% \mathrm{CaO}, 14 \% \mathrm{MgO}$ and $85 \%$ neutralizing power. The pots were subjected to wetting and drying cycles. Experimental design was a complete block with three replications. Pots were water everyday to maintain soil moisture at about field capacity during growth cycle. Shoot and grain were separated at harvest and material was dried in an oven at $70{ }^{\circ} \mathrm{C}$ to a constant weight. Top-root ratio was 
calculated by using the following formula (Fageria 1992):

Top-root ratio $=\frac{\text { Tops dry weight }(\text { grain plus straw })}{\text { Roots dry weight }}$

Root dry weight efficiency index (RDWEI) for $\mathrm{N}$ use efficiency of genotypes was calculated using the following formula as proposed by Fageria (2009):

$$
\begin{aligned}
\mathrm{RDWEI}= & \frac{\text { Root dry weight at low } N \text { rate }}{\text { Average root dry weight of } 20 \text { genotypes at low } N \text { rate }} \mathrm{X} \\
& \frac{\text { Root dry weight at high } N \text { rate }}{\text { Average root dry weight of } 20 \text { genotypes at high } N \text { rate }}
\end{aligned}
$$

Genotypes having RDWEI values $>1$ were classified as efficient, genotypes having RDWEI values, between 0.5 and 1 were classified as moderately efficient and those with RDWEI values $<0.5$ were classified as inefficient in $\mathrm{N}$ use. At the time of harvesting, roots from each pot were removed manually to determine maximum length and dry weight. Roots were washed in water including distilled water several times before drying to a constant weight. Data were analyzed by analysis of variance and means were compared by Tukeys test at the 5\% probability level.

\section{Results and discussion}

Root length

Nitrogen X genotype interaction was significant for root length and root dry weight; therefore data are reported separately for two $\mathrm{N}$ rates (Table 1). Root length varied from $27 \mathrm{~cm}$ produced by genotype BRA01600 to $43 \mathrm{~cm}$ produced by genotype BRA032039, with an average value of $30.49 \mathrm{~cm}$ at the low N rate $(0 \mathrm{mg} \mathrm{N} / \mathrm{kg})$. Similarly at high $\mathrm{N}$ rate $(300 \mathrm{mg} \mathrm{N} / \mathrm{kg})$, root length ranged from $21 \mathrm{~cm}$ produced by genotype BRA01506 $\mathrm{cm}$ to $40.33 \mathrm{~cm}$ produced by genotype BRS Sertaneja, with an average value of 31.99 $\mathrm{cm}$. Overall, root length was $5 \%$ higher at the higher $\mathrm{N}$ rate compared to lower $\mathrm{N}$ rate. However, $35 \%$ genotypes produced lower root length at the higher $\mathrm{N}$ rate compared to lower $\mathrm{N}$ rate. Fageria (1992) reported higher root length of rice at low $\mathrm{N}$ rate compared to high $\mathrm{N}$ rate in nutrient solution. Fageria (1992) also reported that at nutrient deficient levels, root length is higher compared to high nutrient levels because tendency of plants to tap nutrients from deeper soil layers.

\section{Root dry weight}

Root dry weight varied from $0.87 \mathrm{~g} /$ plant produced by genotype BRA01596 to $1.78 \mathrm{~g} / \mathrm{plant}$ produced by genotype BRA052034, with an average value of $1.38 \mathrm{~g} / \mathrm{plant}$ at the lower $\mathrm{N}$ rate $(0 \mathrm{mg} \mathrm{N} / \mathrm{kg})$. At the higher $\mathrm{N}$ rate $(300 \mathrm{mg} \mathrm{N} / \mathrm{kg}$ ), root dry weight ranged from $0.40 \mathrm{~g} /$ plant produced by genotype BRA01506 to 4.14 $\mathrm{g} /$ plant produced by genotype BRA052023 g/plant, with an average value of $2.72 \mathrm{~g} / \mathrm{plant}$. Overall, root dry weight was $97 \%$ higher at the higher $\mathrm{N}$ rate compared to lower N rate. Fageria and Baligar (2005), and Fageria (2009) reported that $\mathrm{N}$ fertilization improved root dry weight in crop plants, including upland rice. The positive effect of $\mathrm{N}$ o root dry matter has been previously documented (Fageria 2009).

\section{Visual evaluation of root growth}

Overall, root growth was reduced in the $0 \mathrm{mg} \mathrm{N} / \mathrm{kg}$ treatment compared to $300 \mathrm{mg} \mathrm{N} / \mathrm{kg}$ of soil. However, there were differences among genotypes in root growth visually observed as length as well as weight. For example, root growth of genotypes BRA052015 was having minimum difference in length as well as weight at two $\mathrm{N}$ rates. Under low $\mathrm{N}$ rate, roots were thicker and having less hairs compared to higher $\mathrm{N}$ rate. Roots were thinner and root hairs were also fine at the high $\mathrm{N}$ rate compared to lower $\mathrm{N}$ rate. The root diameter and hairs may be indicative of the nutrient absorption capacity of the root system (Fageria 2009). Thinner roots with fine fine hairs can absorb more nutrients and water compared to thicker roots with less fine hairs. These results concur with published results on the effects of $\mathrm{N}$ fertilization on root characteristics (Drew et al. 1993).

\section{Classification of genotypes for $N$ use efficiency}

Based on RDWEI, most efficient genotypes in N use efficiency were BRA052045, BRA052023, BRA052033, BRA042160, BRA032039, BRA052015, BRA052034, BRA052053, BRA02601, BRA02535, BRS Primavera, BRA042094, BRS Sertaneja and BRA032048. The three genotypes moderately efficient in N use efficiency were BRA032051, BRA042156 and BRA032033. Remaining three genotypes which were 
Table 1. Root length and root dry weight of 20 upland rice genotypes as influenced by nitrogen fertilization.

\begin{tabular}{|c|c|c|c|c|}
\hline \multirow[t]{2}{*}{ Genotype } & \multicolumn{2}{|c|}{ Root length $(\mathrm{cm})$} & \multicolumn{2}{|c|}{ Root dry weight (g/plant) } \\
\hline & $0 \mathrm{mg} \mathrm{N} / \mathrm{kg}$ & $300 \mathrm{mg} \mathrm{N} / \mathrm{kg}$ & $0 \mathrm{mg} \mathrm{N} / \mathrm{kg}$ & $300 \mathrm{mg} \mathrm{N} / \mathrm{kg}$ \\
\hline BRA01506 & $34.67 \mathrm{ab}$ & $21.00 \mathrm{~cd}$ & $0.92 \mathrm{a}$ & $0.40 \mathrm{f}$ \\
\hline BRA01596 & $30.00 \mathrm{~b}$ & $15.67 \mathrm{~d}$ & $0.87 \mathrm{a}$ & $0.45 \mathrm{f}$ \\
\hline BRA01600 & $27.00 \mathrm{ab}$ & $25.33 \mathrm{bcd}$ & $1.14 \mathrm{a}$ & $1.03 \mathrm{ef}$ \\
\hline BRA02535 & $31.67 \mathrm{ab}$ & $30.00 \mathrm{abcd}$ & $1.33 \mathrm{a}$ & $3.25 \mathrm{abcd}$ \\
\hline BRA02601 & $28.00 \mathrm{~b}$ & $32.67 \mathrm{abc}$ & $1.11 \mathrm{a}$ & $3.73 \mathrm{ab}$ \\
\hline BRA032033 & $30.00 \mathrm{a}$ & $28.00 \mathrm{abcd}$ & $1.12 \mathrm{a}$ & $2.41 \mathrm{~cd}$ \\
\hline BRA032039 & $43.00 \mathrm{a}$ & $34.67 \mathrm{abc}$ & $1.24 \mathrm{a}$ & $3.77 \mathrm{ab}$ \\
\hline BRA032048 & $28.50 \mathrm{~b}$ & $32.00 \mathrm{abc}$ & $1.05 \mathrm{a}$ & $3.62 \mathrm{abc}$ \\
\hline BRA032051 & $30.67 \mathrm{ab}$ & $35.67 \mathrm{ab}$ & $1.31 \mathrm{a}$ & $2.82 \mathrm{bcd}$ \\
\hline BRA042094 & $30.33 b$ & $38.00 \mathrm{ab}$ & $1.78 \mathrm{a}$ & $2.31 \mathrm{de}$ \\
\hline BRA042156 & $29.33 b$ & $33.00 \mathrm{abc}$ & $1.19 \mathrm{a}$ & $2.84 \mathrm{bcd}$ \\
\hline BRA042160 & $29.67 b$ & $32.50 \mathrm{abc}$ & $1.51 \mathrm{a}$ & 3.33abcd \\
\hline BRA052015 & $31.00 \mathrm{ab}$ & $35.00 \mathrm{abc}$ & $1.67 \mathrm{a}$ & $2.83 \mathrm{bcd}$ \\
\hline BRA052023 & $29.67 b$ & 26.50abcd & $1.48 \mathrm{a}$ & $4.14 \mathrm{a}$ \\
\hline BRA052033 & $30.33 b$ & $31.33 \mathrm{abc}$ & $1.56 \mathrm{a}$ & 3.38abcd \\
\hline BRA052034 & $29.00 \mathrm{~b}$ & $37.67 \mathrm{ab}$ & $1.78 \mathrm{a}$ & $2.58 \mathrm{bcd}$ \\
\hline BRA052045 & $28.67 b$ & $37.67 \mathrm{ab}$ & $1.75 \mathrm{a}$ & $3.66 \mathrm{abc}$ \\
\hline BRA052053 & $29.00 \mathrm{~b}$ & $36.50 \mathrm{ab}$ & $1.65 \mathrm{a}$ & $2.72 \mathrm{bcd}$ \\
\hline BRS Primavera & $29.33 b$ & $36.33 \mathrm{ab}$ & $1.68 \mathrm{a}$ & $2.49 \mathrm{bcd}$ \\
\hline BRS Sertaneja & $30.00 \mathrm{~b}$ & $40.33 a$ & $1.45 \mathrm{a}$ & $2.68 \mathrm{bcd}$ \\
\hline Average & 30.49 & 31.99 & 1.38 & 2.72 \\
\hline \multicolumn{5}{|l|}{ F-Test } \\
\hline $\mathrm{N}$ rate $(\mathrm{N})$ & NS & & $*$ & \\
\hline Genotype (G) & $* *$ & & $* *$ & \\
\hline $\mathrm{NXG}$ & $* *$ & & $* *$ & \\
\hline $\mathrm{CV}(\%)$ & 14.25 & & 15.86 & \\
\hline
\end{tabular}

* Significant at the 5 and 1\% probability levels, respectively. Means followed by the same letter in the same column are not significant at the $5 \%$ probability level by Tukey test.

inefficient were BRA01506, BRA01596 and BRA01600. Limited data are available in the literature for classification of upland rice genotypes on the basis of root growth and hence, can not be compared with the published work.

\section{Conclusions}

Knowledge of root growth is important to know the ability of a crop to tap soil nutrients and water necessary to sustain plant growth. A significant interaction between genotypes and $\mathrm{N}$ rates was found for root growth because some genotypes were highly response to the $\mathrm{N}$ application while others were not. Thus genotypes selection for $\mathrm{N}$ use efficiency is an important aspect for improving root growth and consequently yield of upland rice in Brazilian Oxisols. Nitrogen fertilization produced thinner roots with fine root hairs compared with without $\mathrm{N}$ fertilization treatment. The genotypes were classified in three groups based on root dry weight efficiency index. Among 20 genotypes evaluated, $70 \%$ fell into efficient group, $15 \%$ fell into moderately efficient group and $15 \%$ fell into inefficient group.

\section{References}

Drew MC, Saker LR, Ashley TW (1993) Nutrient supply and the growth of the seminal root system in barley. Journal of Experimental Botany 24, 1189-1202.

Fageria, NK (1992) 'Maximizing crop yields'. (New York: Marcel Dekker).

Fageria NK (2002) Nutrient management for improving upland rice productivity and sustainability. Communications in Soil Science and Plant Analysis 32, 2603-2629.

Fageria NK (2007) Yield physiology of rice. Journal of Plant Nutrition 30, 843-879.

Fageria NK (2009) 'The use of nutrients in crop plants'. (New York: CRC Press).

Fageria NK, Baligar VC (2005) Enhancing nitrogen use efficiency in crop plants. Advances in Agronomy 80, 63-152

Sainju UM, Singh BP, Whitehead WF (2005) Tillage, cover crops, and nitrogen fertilization effects on cotton and sorghum root biomass, carbon, and nitrogen. Agronomy Journal 97, 1279-1290. 